\title{
The geology of Cuba: A brief overview and synthesis
}

M.A. Iturralde-Vinent, Cuban Academy of Sciences, Cuba, maivcu@ gmail.com; A. García-Casco, Departamento de Mineralogía y Petrología, Universidad de Granada, Fuentenueva s/n, 18002 Granada, Spain; and Instituto Andaluz de Ciencias de la Tierra, CSIC-Universidad de Granada, Granada, Spain; Y. Rojas-Agramonte, Institut für Geowissenschaften, Johannes Gutenberg-Universität, Becherweg 21 D-55099 Mainz, Germany; J.A. Proenza, Departament de Mineralogia, Petrologia i Geologia Aplicada Facultat de Geologia, Universitat de Barcelona (UB), Martí i Franquès s/n, 08028 Barcelona, Spain; J.B. Murphy, Department of Earth Sciences, St. Francis Xavier, P.O. Box 5000, Antigonish, Nova Scotia, B2G 2W5, Canada; and R.J. Stern, Geosciences Department, University of Texas at Dallas, Richardson, Texas 75080 USA

\section{ABSTRACT}

Cuba is the largest island in the Greater Antilles, and its geology records three important episodes: (1) the Jurassic breakup of North and South America (Pangea) and associated passive margin and oceanic sedimentary and magmatic evolution; (2) the sedimentary, magmatic, and metamorphic evolution of an intra-oceanic Cretaceous-Paleogene ophiolite-arc complex; and (3) the Paleogene "soft collision" and transfer of the NW Caribbean plate (and Cuba) to the North American plate. Thick sequences of JurassicCretaceous strata (conglomerates, sandstones, limestones, dolostones, shales) and interlayered basaltic rocks characterize passive margin sequences preserved in the Guaniguanico terrane (western Cuba, related to the Mayan passive margin and the Gulf of Mexico) and the Bahamas Platform borderlands (north of Cuba). Passive margin deposition ceased in latest Cretaceous time, when increasing relief of accreted (overriding) oceanic arc and ophiolite complexes shed coarse sediments (olistostrome and flysch), followed by carbonate deposition. Fragments of the intervening oceanic lithosphere (Proto-Caribbean, connected to the Central Atlantic) and fore- and back-arc oceanic lithosphere (Caribbean, of Pacific origin) occur as tectonic fragments detached from the ophiolitic units, including serpentinized harzburgites and dunites, banded and isotropic gabbros, basalts (tholeiitic and fore-arc basalts, locally with boninites) and Late Jurassic (Tithonian) through Late Cretaceous (Coniacian and younger) oceanic sediments. Arc activity in the Cuban segment of the Greater Antilles produced sedimentary, volcanic, and plutonic rocks during Cretaceous times (ca. 135-70 Ma). A new arc developed in eastern Cuba during Paleocene-middle Eocene times. Cuban arc sequences include island-arc tholeiitic, calcalkaline, and alkaline bimodal suites of volcanic and plutonic rocks. Remnants of ProtoCaribbean oceanic lithosphere occur as exhumed mélangebearing eclogite-, blueschist-, and garnet-amphibolite-facies tectonic blocks (oldest age ca. $120 \mathrm{Ma}$ ) within a serpentinite matrix intercalated with, or at the base of, the overthrusted ophiolitic bodies. Cuban Cretaceous arc magmatic activity ended due to the subduction of Proto-Caribbean passive margin sequences of the Caribeana terrane, an offshore protuberance of Yucatan. This event formed strongly deformed high-pressure metasedimentary and metaigneous rocks at ca. $70 \mathrm{Ma}$, when the Caribbean plate began to collide with North America. The collision, which included overriding of the ophiolitic and arc units over both subducted and unsubducted passive margin sequences, also produced synorogenic basins and filled them, a process that continued until ca. $40 \mathrm{Ma}$. This foldbelt was succeeded by local uplift and subsidence to form late Eocene-Recent unconformable post-orogenic continental basins.

\section{INTRODUCTION AND GEOLOGIC SETTING}

Cuba has had a very interesting geologic evolution. The island is geographically very near the United States, but for political reasons, U.S. geoscientists have not been able to study it much. In this overview ${ }^{1}$, we highlight the geology of Cuba. Useful publications on Cuban geology produced during the past quarter century can be found in Ceballos Izquierdo and Iturralde-Vinent (2016). We hope that the improving political situation will increase mutually beneficial interactions in the future. A few relevant geographic and demographic facts about Cuba are listed in Table 1.

Cuba is the largest island in the Greater Antilles and has been part of the North American plate (NOAM) since late Eocene time. It is separated from other Greater Antilles islands by the North

Table 1. Facts about Cuba

\begin{tabular}{|c|c|}
\hline Size & $\begin{array}{l}109,884 \mathrm{~km}^{2} \text { (about the size of U.S. state of } \\
\text { Tennessee). The main island is } 1250 \mathrm{~km}(780 \mathrm{mi}) \\
\text { long. Cuba is the largest island in the Caribbean and } \\
\text { the } 17 \mathrm{th} \text { largest island in the world. }\end{array}$ \\
\hline Geography & $\begin{array}{l}\text { Cuba consists of flat to rolling plains as well as low } \\
\text { mountain chains with peaks between } 600 \text { and } 1974 \mathrm{~m} \\
\text { (1968.5 and } 6476 \mathrm{ft}) \text {, surrounded by shallow platforms, } \\
\text { keys, and islets, as well as deep depressions, such as } \\
\text { the Bartlett trough ( } 6810 \mathrm{~m} \text { [ } \sim 2.23 \mathrm{mi}]) \text {. }\end{array}$ \\
\hline Coastline & $3740 \mathrm{~km}(2324 \mathrm{mi})$ \\
\hline Highest point & Pico Turquino (1974 m [6476 ft]) \\
\hline Population (2014) & $11,238,317$ \\
\hline $\begin{array}{l}\text { Political } \\
\text { subdivisions }\end{array}$ & $\begin{array}{l}15 \text { provinces and one special municipality: Isla de la } \\
\text { Juventud. }\end{array}$ \\
\hline Official language & Spanish \\
\hline $\begin{array}{l}\text { Geological } \\
\text { resources }\end{array}$ & $\begin{array}{l}\text { Cuba's most important mineral resource is nickel, with } \\
21 \% \text { of total exports in } 2011 \text {. The output of Cuba's } \\
\text { nickel mines that year was } 71,000 \text { tons, approaching } \\
4 \% \text { of world production. As of } 2013 \text {, its reserves were } \\
\text { estimated at } 5.5 \text { million tons, over } 7 \% \text { of the world } \\
\text { total. Cuba is also a major producer of cobalt, a by- } \\
\text { product of nickel mining operations. Oil exploration in } \\
2005 \text { by the USGS revealed that the North Cuba basin } \\
\text { could produce } ~ 4.6 \text { billion barrels }\left(730,000,000 \mathrm{~m}^{3}\right) \text { to } \\
9.3 \text { billion barrels }\left(1.48 \times 10^{9} \mathrm{~m}^{3}\right) \text { of oil. }\end{array}$ \\
\hline
\end{tabular}

GSA Today, v. 26, no. 10, doi: 10.1130/GSATG296A.1.

${ }^{1}$ This article was written as a companion to the Pardee Symposium "Geologic Evolution of Cuba" presented at the 25-28 September 2016 GSA Annual Meeting. 

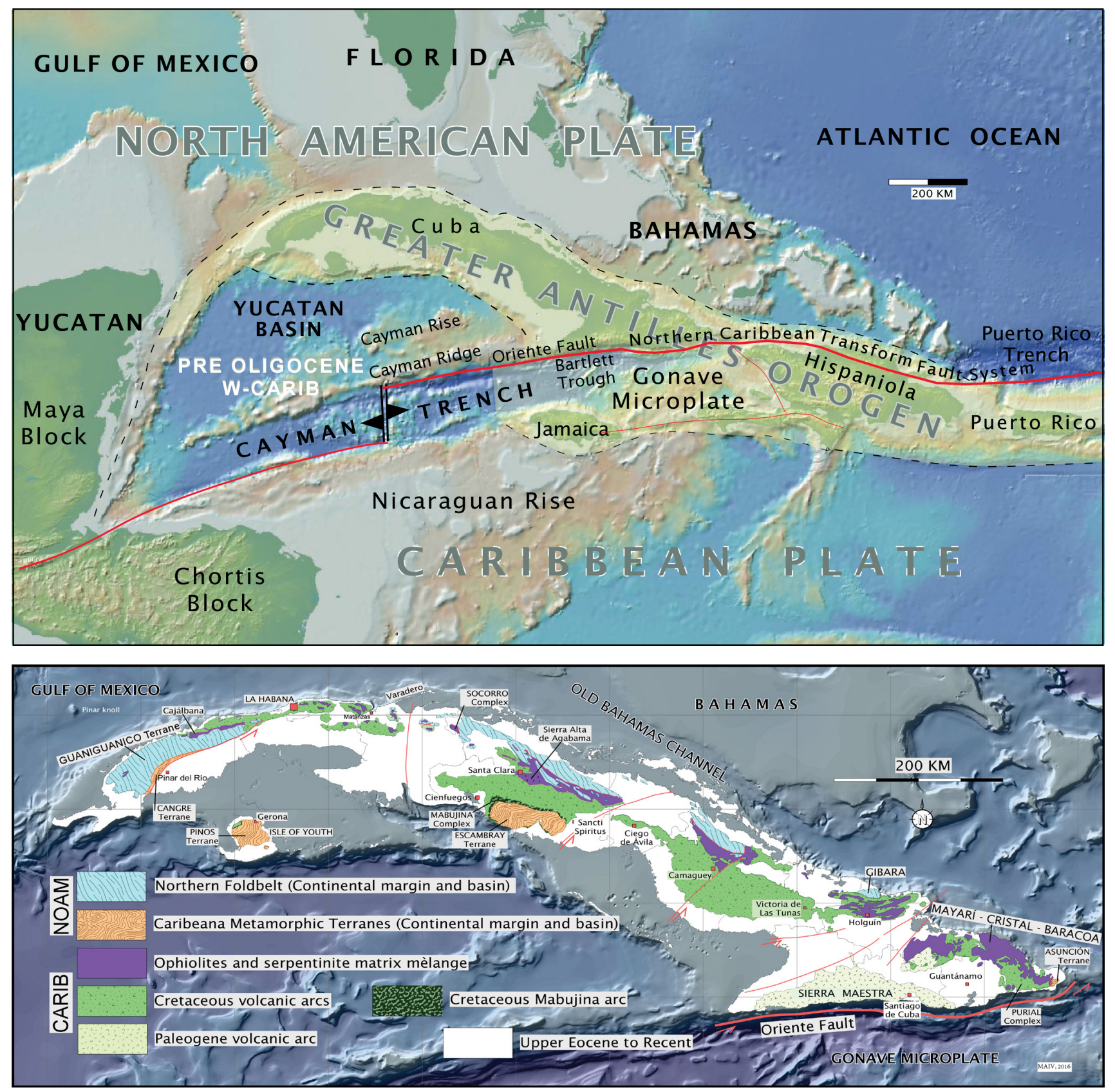

Figure 1. (Top) Tectonic map of the northern Caribbean region. (Bottom) Generalized geologic-tectonic map of Cuba modified from Iturralde-Vinent (2011).

Caribbean Transform Fault System (including the Oriente Fault), which defines the present North American-Caribbean (NOAMCARIB) plate boundary south of Cuba (Fig. 1A).

The Greater Antilles Arc began to form 135 m.y. ago, after the breakup of Pangea, along the leading edge of CARIB, due to SW-dipping subduction of NOAM beneath NW CARIB. The Cuban arc finally collided with Florida and the Bahamian platform in middle to late Eocene time (ca. 48-40 Ma). About this time, the Cayman spreading ridge and the Oriente transform formed to the south (Fig. 1A), resulting in a new NOAM-CARIB plate boundary zone (PBZ) along the new fault system (Burke et al., 1978). This plate reorganization also resulted in the formation of the small Gonave plate SE of Cuba (Fig. 1A). These events transferred NW CARIB, including Cuba, to NOAM (Pindell and Kennan, 2009).

The geology of Cuba is dominated by three lithotectonic associations, which reflect its evolution as a Cretaceous-Paleogene convergent margin: (1) deformed (para)autochthonous NOAM Jurassic and Cretaceous continental margin and basin sections and Paleocene-Eocene synorogenic foredeep deposits; (2) oceanic lithosphere and associated sedimentary rocks that formed on CARIB, including ophiolite complexes and serpentinite mélanges. These oceanic crustal assemblages are associated with ca. 135-47 Ma magmatic activity and interbedded with or overlain by synorogenic basins; and (3) (neo)autochthonous late Eocene to Recent deposits that unconformably overlie the two older 
units (Figs. 1B and 2; Iturralde-Vinent, 2011). Many of these units were partially subducted, metamorphosed, and exhumed. These lithotectonic associations are briefly summarized in the following sections.

\section{NORTH AMERICAN (NOAM) ACCRETED DEPOSITS}

North American igneous rocks and sediments originally formed along the Yucatan and Bahamas passive margins and elsewhere in the Proto-Caribbean basin. These units now crop out as juxtaposed fold-and-thrust belts of the Guaniguanico terrane, the Northern Foldbelt, and the metamorphic Caribeana terranes (Fig. 1B).

\section{Guaniguanico Terrane}

This terrane includes Early(?) Jurassic to latest Cretaceous passive margin siliciclastics, marine basalts, limestone, shale, and chert that record the origin and evolution of the ProtoCaribbean seaway (Fig. 2; Pszczółkowski, 1999; IturraldeVinent, 2011). These rocks are overlain by Paleocene to Lower Eocene synorogenic foredeep sedimentary rocks, including limestones, flysch, and olistostrome deposits. This ensemble was overthrust by ophiolitic and volcanic arc units (Bralower and Iturralde-Vinent, 1997).

\section{Northern Foldbelt}

This belt preserves the southern edge of the Mesozoic FloridaBahamas platform deposits (Figs. 1B and 2; Meyerhoff and Hatten, 1974). The Northern Foldbelt and the Guaniguanico Terrane share similar Late Jurassic and Cretaceous ProtoCaribbean marine deposits. Between Paleocene and early Upper Eocene time, a forebulge and synorogenic foredeep developed with olistostrome, flysch, and carbonate deposition ahead of the leading edge of CARIB; extensive overthrusting also occurred
(Iturralde-Vinent, 2013; Iturralde-Vinent et al., 2008; van Hinsbergen et al., 2009).

\section{Caribeana Metamorphic Terranes}

These terranes comprise Proto-Caribbean Jurassic-Cretaceous passive margin and oceanic protoliths (Figs. $1 \mathrm{~B}$ and 2) that were subducted and accreted to Cuba 75-60 m.y. ago (García-Casco et al., 2008). Caribeana is represented in Cuba by (1) the Cangre glaucophane-bearing terrane; (2) the Pinos metamorphic terrane; (3) the Escambray greenschist to eclogite facies complex with inverted metamorphic structure; and (4) the Asunción lawsonite and glaucophane-bearing terrane (Figs. $1 \mathrm{~B}$ and 2; Somin and Millán, 1981; García-Casco et al., 2008; Despaigne et al., 2016).

\section{CARIBBEAN PLATE}

CARIB allochthonous units are fragments of Pacific oceanic lithosphere that migrated into their present positions during Cretaceous time. An integrated geologic (Whattam and Stern, 2015) and geodynamic (Gerya et al., 2015) case has been made that Caribbean plate formation began when the Galapagos mantle plume head impinged on the Proto-Caribbean seaway in Early Cretaceous time. Alternatively, Pindell et al. (2012) proposed that onset of subduction at ca. $135 \mathrm{Ma}$ occurred along an interAmerican transform fault with no influence of plume head. The Greater Antilles subduction zone along the leading edge of the Caribbean plate was responsible for the subduction of at least $1500 \mathrm{~km}$ of Proto-Caribbean and NOAM lithosphere in a SW-dipping intra-oceanic subduction zone (Figs. 1B and 2). The following CARIB units can be distinguished in Cuba.

\section{Ophiolites and Ophiolitic Mélange}

These rocks outcrop discontinuously for more than $1000 \mathrm{~km}$ along the northern margin of Cuba. They were obducted onto the

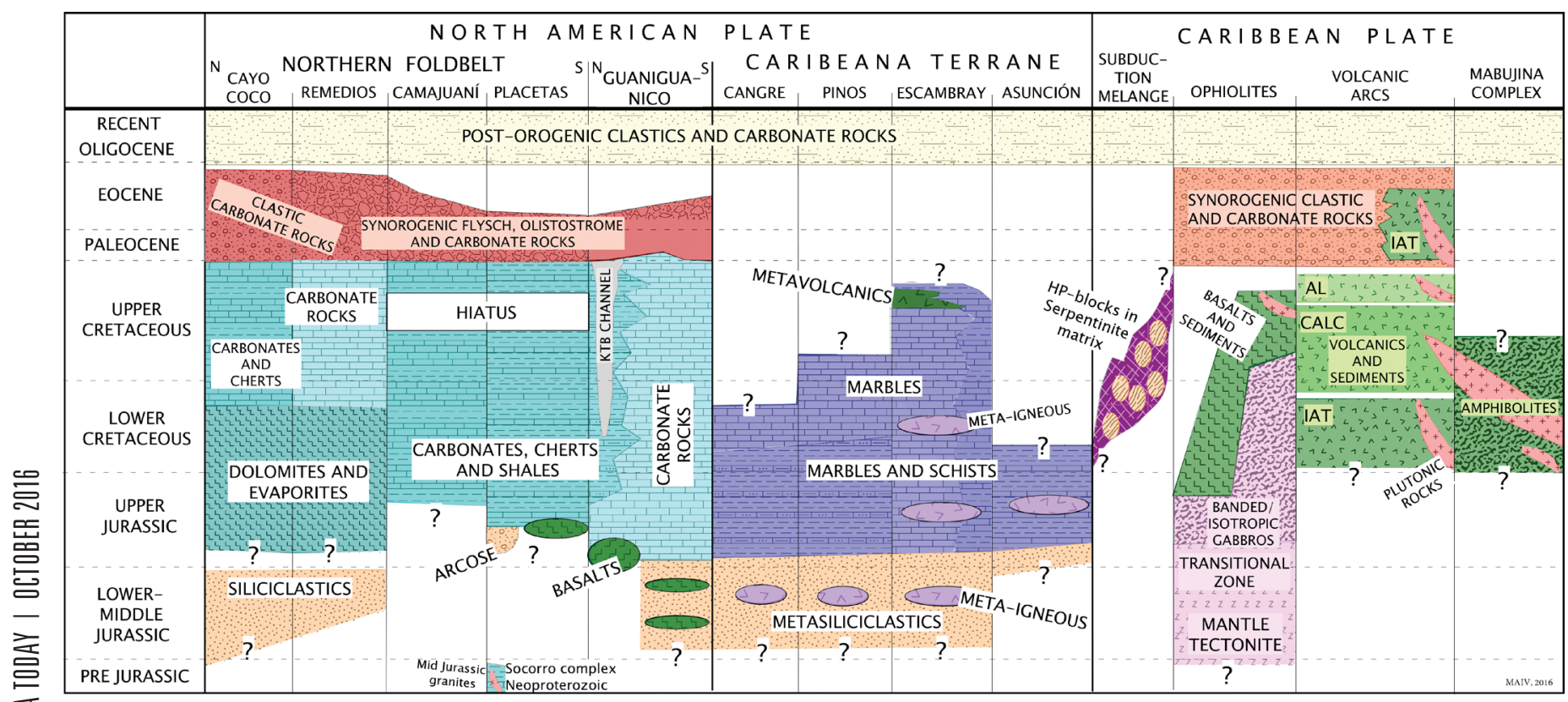

Figure 2. Generalized tectonic-stratigraphic chart of Cuba modified from Iturralde-Vinent (2011). Under "volcanic arcs," abbreviations refer to island arc tholeiite (IAT), alkaline suites (AL), and calc-alkaline suites (CALC). KTB channel refers to a deep erosional channel cut due to the Cretaceous-Tertiary boundary mass flows from the platform margins due to the impact. 
NOAM paleo-margin in latest Cretaceous to late Eocene times. Ophiolites include serpentinized harzburgites and dunites, banded and isotropic gabbros, basalts, and hyaloclastites (tholeiitic and fore-arc basalts, locally with boninitic compositions) overlain by Late Jurassic (Tithonian) through Late Cretaceous (Coniacian and younger) oceanic sediments. Sheeted dikes and isotropic gabbro are rare (Figs. 2 and 3C; Iturralde-Vinent, 1996). The available petrological, geochemical, and geochronological data suggest that Cuban ophiolites include both mid-ocean-ridge and supra-subduction zone types (Kerr et al., 1999; Proenza et al., 2006; Marchesi et al., 2007; Lázaro et al., 2015). However, the widespread occurrence in the ophiolites of very refractory mantle peridotites as well as extrusive rocks with geochemical characteristics of island arcs indicate that the protoliths of most Cuban ophiolites formed above a subduction zone by both fore-arc and back-arc spreading. During subduction and obduction, the
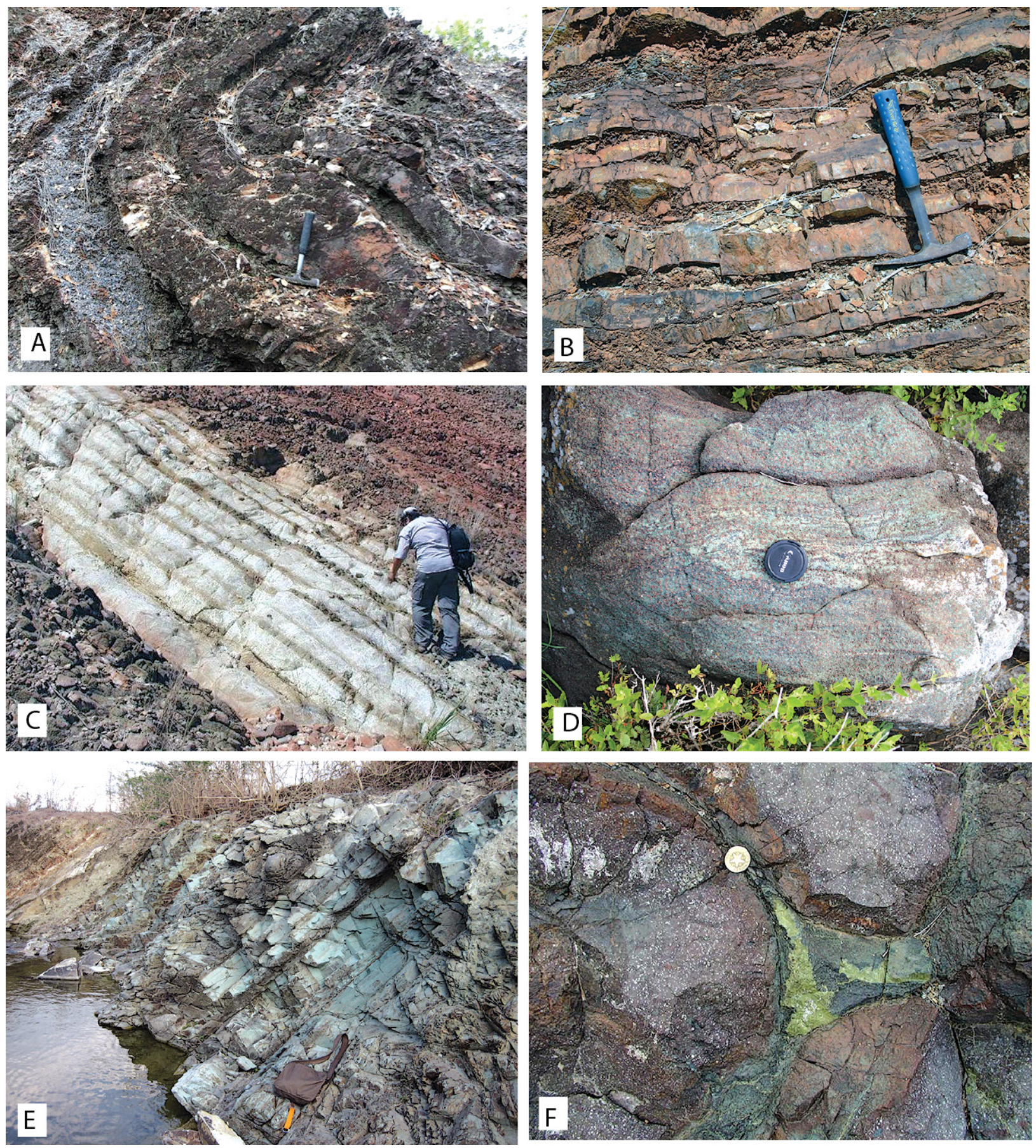

Figure 3. Outcrop photographs of some Cuban geologic units. (A) Recumbent fold in Jurassic continent-derived siliciclastics, Guaniguanico terrane, Alturas de Pizarra del Norte, Pinar del Río. (B) Aptian-Albian pelagic cherts of the Proto-Caribbean seafloor. Sierra de Rosario, Guaniguanico terrane, Pinar del Río. (C) Layered gabbros of the Moa-Baracoa Ophiolites, near Moa. (D) Block of mid-oceanic-ridge-basaltderived epidote-Na-Ca amphibole eclogite in serpentinite mélange (north of Santa Clara city, central Cuba). (E) Intercalated well-bedded finegrained green tuff with conglomerate and sandstones of the Brujas Formation (Cretaceous volcanic arc) at Palmarito Dam, south of Santa Clara. (F) Eocene pillow basalts and green ribbon cherts of the Paleogene arc at Sierra Maestra. 
ophiolites were dismembered, and exotic fault blocks from NOAM and the Cretaceous arcs were incorporated within the deformed ophiolitic bodies. Associated strips of subduction-related mélanges contain high-pressure(high- $P$ ) blocks (eclogite-, amphibolite-, blueschist-, and high- $P$ greenschist-facies rocks and jadeitite) in a serpentinite-matrix. These mélanges formed in a subduction zone from 120 Ma through latest Cretaceous (65 Ma; Fig. 3D); similar mélanges with high- $P$ blocks occur as olistoliths within the foredeep basin and as tectonic slices within the Escambray complex (García-Casco et al., 2006; Blanco-Quintero et al., 2011; Cárdenas-Párraga et al., 2012).

\section{Cretaceous Arc Complexes}

Three stages of Cretaceous island arc volcano-sedimentary and plutonic rocks, separated by unconformities, are found in Cuba. Each arc sequence shows a distinct geochemical signature (Fig. 2). They are tectonically intercalated by thrust faulting with ophiolitic rocks and serpentinite mélanges and tectonically overlie the NOAM terranes (Figs. 1B and 2; Díaz de Villalvilla, 1997; Iturralde-Vinent and Lidiak, 2006; Marchesi, et al., 2007). In eastern Cuba (Purial complex) arc rocks metamorphosed in greenschist, and high- $P$, low-temperature blueschist-facies were partly subducted during the latest Cretaceous (García-Casco et al., 2008; Lázaro et al., 2015). Arc-related granitoid plutons range in age from ca. 89-83 Ma in the Santa Clara province (westcentral Cuba) and 104-75 Ma in Camagüey province (east-central Cuba) (Hall et al., 2004; Rojas-Agramonte et al., 2011).

\section{Mabujina Meta-Arc Complex}

This complex structurally underlies the non-metamorphic arc rocks in Central Cuba (Figs. 1B and 2) and is composed of deformed gabbros, basalts, basaltic andesites, and pyroclastic rocks that were deformed and metamorphosed into the greenschist and amphibolite facies (Somin and Millán, 1981; Blein et al., 2003). Concordant and crosscutting granitic-gneissic rocks occur as pre-metamorphic (ca. $133 \mathrm{Ma}$ ), syn-metamorphic (ca. $93 \mathrm{Ma}$ ), and post-metamorphic intrusions/injections (ca. 89-83 Ma) (Grafe et al., 2001; RojasAgramonte et al., 2011). Several lines of evidence suggest that the Mabujina protoliths were detached from the Pacific margin of North America and accreted to the base of the Cuban Cretaceous arc complex at ca. 93-91 Ma (A. García-Casco and Y. Rojas-Agramonte, 2016, personal commun.).

\section{Synorogenic Basins and Paleogene Arc}

Late Campanian to late Eocene sedimentary strata unconformably overlie Cretaceous arc and ophiolite complexes (Fig. 2) with clastic deposits derived from the Cretaceous igneous substrate and interbedded carbonates (Iturralde-Vinent, 2015). In eastern Cuba, these deposits are interbedded laterally with Danian-middle Eocene arc lavas and volcaniclastics. Paleogene intraoceanic arc rocks are restricted to eastern Cuba (Fig. 2). Associated intermediate to felsic plutons are dated at $60.5 \pm 2.2$ to $46.9 \pm 0.1 \mathrm{Ma}$ (Cazañas et al., 1998; Iturralde-Vinent, 2011; Rojas-Agramonte et al., 2004, 2005). South of Sierra Maestra, the arc is truncated by the Oriente transform fault.

\section{LATEST EOCENE TO RECENT DEPOSITS}

Postorogenic latest Eocene to Recent basins and uplifted 8
Deposits include interbedded coarse clastics and limestone, which in Cuba are mildly deformed and characterized by open folds, steeply dipping normal faults, and NE-SW strike-slip faults. These strata are strongly deformed only along the present E-W transform boundary between NOAM and CARIB in southeastern Cuba, with recumbent folds and strike slip, reverse, and normal faults. Following establishment of modern sea level $\sim 8000$ years ago, Cuba attained roughly its present outline (Iturralde-Vinent, 2006).

\section{RESEARCH OPPORTUNITIES}

There is much that can we learn from future studies of Cuba, not only about the island itself but also about the tectonic evolution of the Caribbean region and other important tectonic processes of interest to the global geoscientific community. In the following sections, we briefly outline four promising research avenues: the Jurassic Caribbean, subduction initiation, intra-oceanic arc-trench systems, and collision tectonics.

\section{Jurassic Caribbean}

Better understanding of Cuban geology promises to provide important insights into the fit of Pangea and the origin of protoCaribbean strata. Pre-Mesozoic clasts are found in Eocene, Cretaceous, and Jurassic conglomerates, but the sources of these and of the Jurassic siliciclastics are not well understood. For example, gneiss pebbles of ca. 400 Ma age (Millán and Somin, 1985) and 250-220 Ma (Somin et al., 2006) occur in the Eocene El Guayabo conglomerate of the Pinar del Río region of western Cuba. Focused studies should allow us to assign them to a source and provide a link between the Caribbean terrane and Central or South America. Furthermore, some poorly investigated metasedimentary blocks engulfed in the subduction mélange may sample early Atlantic-Proto-Caribbean oceanic sediments.

\section{Subduction Initiation}

It is important to understand how new subduction zones form. It has recently been suggested that emplacement of the Galapagos plume head formed most of the Caribbean plate, namely the (Caribbean Large Igneous Complex or “CLIP”), and that CLIP emplacement caused lithospheric collapse and formation of new subduction zones (Gerya et al., 2015), a process termed "plumeinduced subduction initiation" (PISI). These subduction zones are argued to have formed around the plume head, perhaps first around the north at ca. $130 \mathrm{Ma}$, then around the southern, western, and northern margin at $85 \pm 5 \mathrm{Ma}$. Alternatively, onset of subduction along the inter-American transform may have occurred with or without influence of the plume head. Studying the great Cuban ophiolite belt (Fig. 1B) provides a great opportunity to test and refine these hypotheses.

\section{Intraoceanic Arc-Trench Systems}

The Cuban arc is beautifully preserved and uplifted above sea level as a result of the soft-collision with NOAM. This gives us a $1000-\mathrm{km}+$ long arc section that may rival the classical arc crustal sections of California, Talkeetna, or Kohistan. The Mabujina Complex in particular promises important glimpses of arc crustal architecture and processes of arc crust formation. Examining potential correlations between CARIB early arc magmas and the evolution of the Mabujina arc and coeval magmatic rocks in the 
eastern Pacific would enhance the understanding of the early evolution of the Caribbean Plate. The subducted section of the Cretaceous arc in eastern Cuba (Purial complex) also offers the opportunity to inspect forearc crustal structure. On the other hand, the well-exposed Cuban Paleogene magmatic arc and its prolongation into Hispaniola require detailed studies in order to improve models for the Cenozoic tectonic evolution of northern CARIB margin. These arc rocks are associated with unusual and poorly understood subhorizontal emplacement of ophiolite thrust sheets and high- $P$ metamorphism of Cretaceous arc suites in eastern Cuba.

\section{Collision Tectonics}

Evidence of NOAM-CARIB collision is well preserved in the rocks of Cuba, and the sequence of plate reorganization events that followed this is mostly understood. The rapidity of the plate reorganization by forming the transform margin south of Cuba arrested collisional deformation at an early stage; this may be the best example of a "soft collision" available for study anywhere in the world. The range of deformation styles and sedimentary responses that occurred during the early stages of collision are well preserved and available for study.

\section{CONCLUSIONS}

In addition to the topics discussed here, Cuban geodiversity embraces natural resources, such as oil and gas, mineral and groundwaters, ore and industrial minerals, marbles and construction materials, and beautiful landscapes, including karst, wetlands, and coral reefs. The fact that we do not have space here to review these important features does not diminish their importance. Further reconstructing of the details of the older geologic framework, exploiting the economic potential, understanding the geomorphic evolution, and preserving the geobiological features are challenges and opportunities for the collective geoscientific community. We hope in the future to see more U.S.-Cuban collaborative studies of Cuban geology and NW Caribbean tectonic evolution.

\section{ACKNOWLEDGMENTS}

We thank G. Draper and J. Pindell for constructive and insightful reviews and GSA Today science editor Gerald Dickens for encouraging this submission.

\section{REFERENCES CITED}

Blanco-Quintero, I.F., Rojas-Agramonte, Y., García-Casco, A., Kröner, A., Mertz, D.F., Lázaro, C., Blanco-Moreno, J., and Renne, P.R., 2011, Timing of subduction and exhumation in a subduction channel: Evidence from slab melts from La Corea mèlange (eastern Cuba): Lithos, v. 127, p. 86-100, doi: 10.1016/j.lithos.2011.08.009.

Blein, O., Guillot, S., Lapierre, H., Mercier de Lepinay, B., Lardeaux, J.M., Millán Trujillo, G., Campos, M., and Garcia, A., 2003, Geochemistry of the Mabujina Complex, Central Cuba: Implications on the Cuban Cretaceous arc rocks: The Journal of Geology, v. 111, p. 89-101, doi: $10.1086 / 344666$.

Bralower, T., and Iturralde-Vinent, M.A., 1997, Micropaleontological dating of the collision between the North American continental margin and the Greater Antilles Volcanic Arc in Western Cuba: Palaios, v. 12, p. 133-150, doi: $10.2307 / 3515303$.

Burke, K., Fox, P.J., and Șengör, A.M.C., 1978, Buoyant ocean floor and the evolution of the Caribbean: Journal of Geophysical Research, v. 83, p. 3949-3954, doi: 10.1029/JB083iB08p03949.
Cárdenas-Párraga, J., García-Casco, A., Harlow, G.E., Blanco-Quintero, I.F., Rojas-Agramonte, Y., and Kröner, A., 2012, Hydrothermal origin and age of jadeitites from Sierra del Convento Mèlange (Eastern Cuba): European Journal of Mineralogy, v. 24, p. 313-331, doi: 10.1127/09351221/2012/0024-2171.

Cazañas, X., Proenza, J.A., Mattietti-Kysar, G., Lewis, J., and Melgarejo, J.C., 1998, Las rocas volcánicas de las series Inferior y Media del Grupo El Cobre en la Sierra Maestra (Cuba Oriental): Volcanismo generado en un arco de islas tholeiítico: Acta Geologica Hispanica, v. 33, p. 57-74.

Ceballos Izquierdo, Y., and Iturralde-Vinent, M., 2016, Biblioteca Digital Cubana de Geociencias: Red Cubana de las Ciencias, http://www.redciencia .cu/geobiblio/inicio.html (last accessed 1 July 2016).

Despaigne, A.I., García-Casco, A., Cáceres Govea, D., Jourdan, F., Wilde S.A., and Millán Trujillo, G., 2016, 25 million years of subduction-exhumation history during the Late Cretaceous-Tertiary in the northwestern Caribbean: The Trinidad dome, Escambray Complex, Central Cuba: American Journal of Science, v. 316, p. 203-240, doi: 10.2475/03.2016.01.

Díaz de Villalvilla, L., 1997, Caracterización geológica de las formaciones volcánicas y volcano-sedimentarias en Cuba central, provincias Cienfuegos, Villa Clara, Sancti Spiritus, in Furrazola-Bermúdez, G., and Nuñez-Cambra, K., eds., Estudios sobre Geología de Cuba: Instituto de Geología y Paleontología, Centro Nacional de la Información Geológica, La Habana.

García-Casco, A., Torres-Roldán, R.L., Iturralde-Vinent, M., Millán, G., Nuñez Cambra, K., Lázaro, C., and Rodríguez Vega, A., 2006, High-pressure metamorphism of ophiolites in Cuba: Geologica Acta, v. 4, p. 63-88, doi: 10.1344/105.000000358.

García-Casco, A., Iturralde-Vinent, M.A., and Pindell, J., 2008, Latest Cretaceous collision/accretion between the Caribbean Plate and Caribeana: Origin of metamorphic terranes in the Greater Antilles: International Geology Review, v. 50, p. 781-809, doi: 10.2747/0020 -6814.50 .9 .781 .

Gerya, T., Stern, R.J., Baes, M., Sobolev, S., and Whattam, S., 2015, Plumeinduced subduction initiation triggered plate tectonics on Earth: Nature, v. 527, p. 221-225, doi: 10.1038/nature15752.

Grafe, F., Stanek, K.P., Baumann, A., Maresch, W.V., Hames, W.E., Grevel, C., and Millán, G., 2001, Rb-Sr and ${ }^{40} \mathrm{Ar} /{ }^{39} \mathrm{Ar}$ mineral ages of granitoid intrusives in the Mabujina unit, Central Cuba: Thermal exhumation history of the Escambray Massif: The Journal of Geology, v. 109, p. 615-631, doi: 10.1086/321966.

Hall, C.M., Kesler, S.E., Russell, N., Piñero, E., Sánchez, R., Pérez, M., Moreira, J., and Borges, M., 2004, Age and tectonic setting of the Camaguey Volcanic-Intrusive Arc, Cuba: Late Cretaceous extension and uplift in the Western Greater Antilles: The Journal of Geology, v. 112, p. 521-542, doi: $10.1086 / 422664$.

Iturralde-Vinent, M.A., ed., 1996, Ofiolitas y arcos volcánicos de Cuba: First Contribution IGCP Project 364, University of Miami Press, 265 p.

Iturralde-Vinent, M.A., 2006, Meso-Cenozoic Caribbean paleogeography: Implications for the historical biogeography of the region: International Geology Review, v. 48, p. 791-827, doi: 10.2747/0020-6814.48.9.791.

Iturralde-Vinent, M.A., ed., 2011, Compendio de Geología de Cuba y del Caribe, Second Edition, CD-ROM. Editorial CITMATEL, ISBN: 9-789592 -572863 .

Iturralde-Vinent, M.A., 2013, Estratigrafía del Cinturón Plegado del Norte de Cuba: Anuario de la Sociedad Cubana de Geología, v. 1, p. 97-136.

Iturralde-Vinent, M.A., 2015, Estratigrafía de las cuencas sinorogénicas del Campaniano tardío al Daniano desarrolladas sobre rocas de arco volcánico y retroarco en Cuba: Anuario de la Sociedad Cubana de Geología, v. 2, p. 27-50.

Iturralde-Vinent, M.A., and Lidiak, E.G., 2006, Caribbean tectonic, magmatic, metamorphic and stratigraphic events: Implication for plate tectonics: Geologica Acta, v. 4, p. 1-5, doi: 10.1344/105.000000355.

Iturralde-Vinent, M.A., Díaz-Otero, C., García-Casco, A., and van Hinsbergen, D., 2008, Paleogene foredeep basin deposits of North-Central Cuba: A record of Arc-Continent Collision between the Caribbean and North American Plates: International Geology Review, v. 50, p. 863-884, doi: 10.2747/0020-6814.50.10.863.

Kerr, A.C., Iturralde-Vinent, M.A., Saunders, A.D., Babbs, T.L., and Tarney, J., 1999, A new plate tectonic model of the Caribbean: Implications from a 
geochemical reconnaissance of Cuban Mesozoic volcanic rocks: GSA Bulletin, v. 111, p. 1581-1599, doi: 10.1130/0016-7606(1999)111<1581: ANPTMO $>2.3 . \mathrm{CO} ; 2$.

Lázaro, C., García-Casco, A., Blanco-Quintero, I.F., Rojas-Agramonte, Y., Corsini, M., and Proenza, J.A., 2015, Did the Turonian-Coniacian plume pulse trigger subduction initiation in the Northern Caribbean? Constraints from ${ }^{40} \mathrm{Ar} /{ }^{39} \mathrm{Ar}$ dating of the Moa-Baracoa metamorphic sole (eastern Cuba): International Geology Review, v. 57, p. 919-942, doi: 10.1080/00206814.2014.924037.

Marchesi, C., Garrido, C.J., Bosch, D., Proenza, J.A., Gervilla, F., Monié, P., and Rodríguez Vega, A., 2007, Geochemistry of Cretaceous magmatism in Eastern Cuba: Recycling of North American continental sediments and implications for subduction polarity in the Greater Antilles paleo-arc: Journal of Petrology, v. 48, p. 1813-1840, doi: 10.1093/petrology/egm040.

Meyerhoff, A.A., and Hatten, C.W., 1974, Bahamas salient of North America: Tectonic framework, stratigraphy and petroleum potential: AAPG Bulletin, v. 58, p. 1201-1239.

Millán, G., and Somin, M., 1985, Condiciones geológicas de las constitución de la capagranito-metamórfica de la corteza terrestre de Cuba: Instituto de Geología y Paleontología, Editorial Academia, 83 p.

Pindell, J., and Kennan, L., 2009, Tectonic evolution of the Gulf of Mexico, Caribbean, and northern South America in the mantle reference frame: An update, in James, K.H., Lorente, M.A., and Pindell, J.L., eds., The Origin and Evolution of the Caribbean Plate: Geological Society, London, Special Publication 328, p. 1-54.

Pindell, J., Maresch, W.V., Martens, U., and Stanek, K., 2012, The Greater Antillean Arc: Early Cretaceous origin and proposed relationship to Central American subduction mélanges: Implications for models of Caribbean evolution: International Geology Review, v. 54, p. 131-143, doi: 10.1080/00206814.2010.510008.

Proenza, J.A., Díaz-Marínez, R., Iriondo, A., Marchesi, C., Melgarejo, J.C., Gervilla, F., Garrido, C.J., Rodríguez-Vega, A., Lozano-Santacruz, R., and Blanco-Moreno, J.A., 2006, Primitive Cretaceous island-arc volcanic rocks in eastern Cuba: The Téneme Formation: Geologica Acta, v. 4, p. 103-121, doi: 10.1344/105.000000360.
Pszczółkowski, A., 1999, The exposed passive margin of North America in western Cuba, in Mann, P., ed., Caribbean Basins: Sedimentary Basins of the World volume 4: Amsterdam, Elsevier Science B.V., p. 93-121.

Rojas-Agramonte, Y., Neubauer, F., Kröner, A., Wan, Y.S., Liu, D.Y., GarcíaDelgado, D.E., and Handler, R., 2004, Geochemistry and age of late orogenic island arc granitoids in the Sierra Maestra, Cuba: Evidence for subduction magmatism in the early Palaeogene: Chemical Geology, v. 213, p. 307-324, doi: 10.1016/j.chemgeo.2004.06.031.

Rojas-Agramonte, Y., Neubauer, F., Handler, R., García-Delgado, D.E., Friedl, G., and Delgado-Damas, R., 2005, Variation of palaeostress patterns along the Oriente Transform Fault, Cuba: Significance for Neogene-Quaternary tectonics of the Caribbean Realm: Tectonophysics, v. 396, p. 161-180, doi: 10.1016/j.tecto.2004.11.006.

Rojas-Agramonte, Y., Kröner, A., García-Casco, A., Somin, M., Iturralde-Vinent, M., Mattinson, J.M., Millán Trujillo, G., Sukar, K., Pérez Rodríguez, M., Carrasquilla, S., Wingate, M.T.D., and Liu, D.Y., 2011, Timing and evolution of Cretaceous island arc magmatism in Central Cuba: Implications for the history of arc systems in the Northwestern Caribbean: The Journal of Geology, v. 119, p. 619-640, doi: 10.1086/662033.

Somin, M.L., and Millán, G., 1981, Geology of the metamorphic complexes of Cuba: Moscow, USSR, Nauka Press, 218 p. (in Russian).

Somin, M.L., Lepechina, E.N., and Tolmacheva, E.V., 2006, El Guayabo gneiss sialic basement boulder in Western Cuba: Geophysical Research Abstracts, v. 8, 03377; Sref-ID: 1607-7962/gra/EGU06-A-03377.

van Hinsbergen, D.J.J., Iturralde-Vinent, M.A., Van Geffen, P.W., García-Casco, A., and van Benthem, S., 2009, Structure of the accretionary prism, and the evolution of the Paleogene northern Caribbean subduction zone in the region of Camagüey, Cuba: Journal of Structural Geology, v. 31, p. 1130-1144, doi: 10.1016/j.jsg.2009.06.007.

Whattam, S., and Stern, R.J., 2015, Late Cretaceous plume-induced subduction initiation along the southern and eastern margins of the Caribbean: The first documented example with implications for the onset of plate tectonics: Gondwana Research, v. 27, p. 38-63, doi: 10.1016/j.gr.2014.07.011.

Manuscript received 6 May 2016; accepted 30 June 2016.

The Web of Science's \#I ranked geology journal for 10 years in a row.
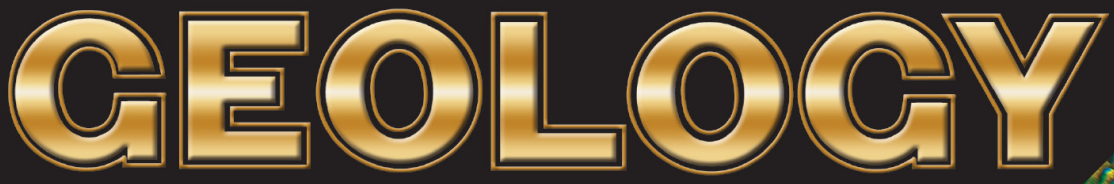

\section{FREE Online Access Included with All 2017 GSA Memberships. \\ .}
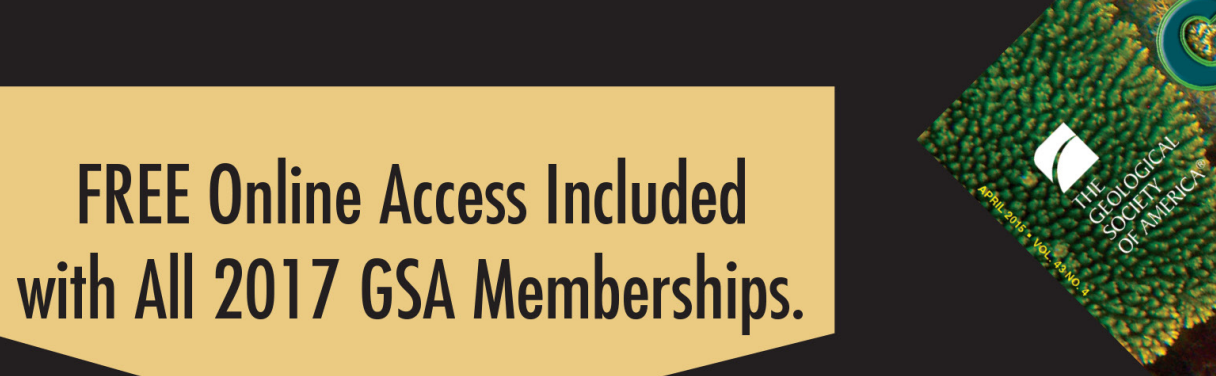